\title{
The influence of seasonality, tide and time of activities on the behavior of Sotalia guianensis (Van Bénéden) (Cetacea, Delphinidae) in Pernambuco, Brazil
}

\author{
Janaina P. Araújo ${ }^{1}$; Maria E. Araújo ${ }^{\text {; }}$; Antonio Souto ${ }^{2}$; Cristiano L. Parente ${ }^{1} \&$ Lena Geise ${ }^{3}$ \\ 1 Departamento de Oceanografia, Universidade Federal de Pernambuco. Avenida Arquitetura, Cidade Universitária, \\ 50730-540 Recife, Pernambuco, Brasil. E-mail: janainabio@yahoo.com.br \\ 2 Departamento de Zoologia, Universidade Federal de Pernambuco. Rua Profesor Moraes Rego, Cidade Universitária, \\ 50670-420 Recife, Pernambuco, Brasil. \\ ${ }^{3}$ Instituto de Biologia, Universidade do Estado do Rio de Janeiro. Rua São Francisco Xavier 524, Maracanã, \\ 20550-013 Rio de Janeiro, Rio de Janeiro, Brasil.
}

\begin{abstract}
Data on Sotalia guianensis Van Bénéden, 1864 occurrence on the beaches of Pernambuco (Northeastern Brazil) is restricted to information on stranding and on printed material from local newspapers; actual observations of such animals have not been published. This study intends to determine the use of habitat, behavioral activities and assess the relationships between environmental factors and the recorded behavior. Observations were conducted on open sea coastal areas, on the beaches of Olinda and Piedade, as well as in sheltered areas, in the ports of Recife and Suape. Monitoring was carried out every month in each area, during two consecutive days, from September 2004 to August 2005. Results corroborate that this species prefers to occupy more protected environments, the port of Recife being the main concentration area for such species. Piedade is just an exploratory area, possibly due to shark occurrence. Olinda is only occasionally used. Concentration areas seem to be used for feeding, and incidence of caudal exhibition suggests that most of the estuarine dolphin prey items are demersal. Environmental conditions (seasonality, tide and time) did not show to be significant when related to the estuarine dolphin behavior.
\end{abstract}

KEY WORDS. Behavioral activities; environmental factors; estuarine dolphin.

RESUMO. Influência da sazonalidade, maré e horário de atividades sobre o comportamento de Sotalia guianensis (Van Bénéden) (Cetacea, Delphinidae) em Pernambuco, Brasil. Dados sobre a ocorrência de Sotalia guianensis Van Bénéden, 1864 nas praias pernambucanas (Nordeste do Brasil) estão limitados a informações de encalhes e de matérias impressas nos jornais locais, sendo inéditas observações efetivas desses animais. Este estudo pretende determinar o uso do habitat, comportamento e avaliar as relações entre fatores ambientais e as condutas registradas. Observações foram realizadas tanto em áreas costeiras de mar aberto, nas praias de Olinda e Piedade, quanto em áreas abrigadas, nos Portos do Recife e Suape. O monitoramento foi realizado por dois dias consecutivos por mês em cada área, no período de setembro de 2004 a agosto de 2005. Os resultados corroboram a preferência da espécie em ocupar ambientes mais protegidos, sendo o porto do Recife o principal ponto de concentração da espécie. Piedade é apenas uma área exploratória, possivelmente pela ocorrência de tubarões. Olinda tem uso ocasional. As áreas de concentração parecem estar destinadas à alimentação, e a incidência de condutas caudais sugere que a maioria das presas dos botos-cinza é demersal. As condições ambientais (sazonalidade, maré e horário) não se mostraram significativas quando relacionadas com as condutas realizadas pelos botos-cinza. PALAVRAS-CHAVE. Atividades comportamentais; boto-cinza; fatores ambientais.

Before Monteiro-FilHo et al. (2002) and CunHa et al. (2005) the estuarine dolphin, Sotalia guianensis (Van Bénéden, 1864), was identified as $S$. fluviatilis and was classified as a fluvial and coastal ecotype. S. guianensis can be found from Honduras to Santa Catarina (DA SILVA \& BEST 1996), although it does not show long displacements (up to $28.97 \mathrm{~km} /$ day) (Flores \& BAzZALO 2004), remaining on the same area all the year round (Simões-
Lopes 1988, Hetzel \& Lodi 1993, Flores 1999, Santos et al. 2001, Rossi-SANTOS et al. 2007).

Information on age classes, growth and reproduction (Rosas \& Monteiro-Filho 2002, Rosas et al. 2003) were possible due to stranding records on S. guianensis (NunEs \& Machado 2001) and skeletons accidentally found during fishing activities (Bittencourt 1984, Borobia \& Barros 1989, Barros \& Teixeira 
1994), contributing to the increase of scientific collections, thus allowing morphometric studies (MonTeiro-FilHo et al. 2002).

Environmental factors, such as depth of places regularly visited, tidal movement, time of the day (WürSIG \& WürsIG 1979) and seasonality (KARCZMARSKI 1999) have been analyzed in order to explain the distribution patterns and habitat use by cetaceous populations. Estuarine dolphin preference for shallow or deep waters varies between the different studied areas and it might be related to each habitat characteristics. Diurnal activities of the $S$. guianensis in Baía da Guanabara (Rio de Janeiro) were influenced by time, but no variation was noticed due to tidal and local depth factors (AzEVEDo et al. 2007). Information on seasonal variation on the $S$. guianensis group size is reduced; however, seasonal differences in the group size were not found on a recent study carried out at Baía de Cispatá, Colombia (Garcia \& Trujillo 2004). Another research, however, has shown the occurrence of smaller groups during spring and winter than during summer and autumn, a feature possibly related to the seasonal variation in dolphins behavior (Daura-Jorge et al. 2005). In Baía Norte, Santa Catarina, DAURA-Jorge et al. $(2004,2007)$ have also found this seasonal variation to affect groups intensity of movement. At the same study site, WEDEKIN et al. (2007) recorded higher concentration of individuals in different locations in the bay. They believed that such variation was due to seasonal changes, albeit differences in the home range of the groups were absent (WEDEKIN et al. 2007).

Results obtained in researches on behavioral patterns have influenced conservation work and show that behavioral attitudes that keep species in their own habitat are relevant (BEISSINGER 1997). The estuarine dolphin feeding activity is normally the most observed one among the ethological studies (Araújo et al. 2003, Garcia \& Trujillo 2004, Daura-Jorge et al. 2005). Resting and socialization behavior are difficult to be recognized, and thus, less recorded (DAURA-Jorge et al. 2005).

There is still little information on the activities of the estuarine dolphins in open sea areas, as most of the studies were carried out in sheltered waters (ARAújo et al. 2003, Lodi 2003, Torres \& Beasley 2003, Flores \& Bazzalo 2004, Daura-Jorge et al. 2004, 2005, Rossi-SANTos et al. 2007, WedeKIn et al. 2007). Moreover, data on the estuarine dolphin occurrence on the beaches of Pernambuco is restricted to records on stranding (Borobia et al. 1991, PARENTE et al. 2006) and information published by the mass media (Diário de Pernambuco and Jornal do Comércio). Actual observations of such animals have not been published, and information regarding the ecological and behavioral aspects are also absent. The only estuarine dolphin known to be monitored in the past, in Pernambuco, is a specimen that remained stranded for 22 days on a natural pond on Maracaípe beach (PARente et al. 2006). Seventeen reports in Pernambuco newspapers were published between 1994 and 2006 regarding this species occurrence. Such reports informed species occurrence from Itamaracá $\left(7^{\circ} 48^{\prime} \mathrm{S}\right.$ and $\left.34^{\circ} 50^{\prime} \mathrm{W}\right)$ to Maracaípe $\left(8^{\circ} 30^{\prime} \mathrm{S}\right.$ and $\left.35^{\circ} 07^{\prime} \mathrm{W}\right)$, stating that the first record occurred in Port of Suape (Diário de Pernambuco, April 9 ${ }^{\text {th }}, 2006$ ).
The purpose of this work was to study $S$. guianensis habitat and behavioral activities in four different sites in Pernambuco (two close areas and two open areas), assessing the possible influences of the environmental factors, period of the day, seasonality and tidal conditions on the observed behavior.

\section{MATERIAL AND METHODS}

\section{Study areas}

The present study was carried out at Bairro Novo beach (Olinda), in Bacia Portuária do Recife (Recife) (port basin), on Piedade beach (Jaboatão dos Guararapes) and in Complexo Industrial Portuário de Suape (Industrial and Port Complex, Ipojuca) (Fig. 1). Depth of the sites where the estuarine dolphins usually stay, considering the studied areas, varied from 5 to $8 \mathrm{~m}$ on the beaches of Olinda and Piedade, and from 13 to $18 \mathrm{~m}$ in the ports of Recife and Suape (V. Manso, pers. comm.). An area up to $10 \mathrm{~m}$ deep is considered shallow and over this is considered deep. The distance between the estuarine dolphins and the observation site is between 30 and $300 \mathrm{~m}$.

A long breakwater, which had been built perpendicular to the coastline, in Olinda $\left(7^{\circ} 59^{\prime} \mathrm{S}, 34^{\circ} 50^{\prime} \mathrm{W}\right)$, had modified the local hydrodynamics, causing aggradation on the sea-wall and water stagnation during the ebb-tide (PEREIRA et al. 1996). The Port of Recife $\left(8^{\circ} 02^{\prime} \mathrm{S}, 34^{\circ} 51^{\prime} \mathrm{W}\right)$ is located in an urban zone and is subject to constant discharges from the Pina Basin, as well as from the Capibaribe and Beberibe Rivers (REsURReIÇÃo et al. 1996). Piedade beach $\left(8^{\circ} 09^{\prime} \mathrm{S}, 34^{\circ} 54^{\prime} \mathrm{W}\right)$ presents two different zones: one without reef formation (where observations were carried out) and another one presenting such kind of formation (SousA \& Cocentino 2004). The mouth of the Jaboatão and Pirapama Rivers, which form Barra das Jangadas Estuary is the northern boundary of Complexo Industrial e Portuário de Suape ( $8^{\circ} 23^{\prime} \mathrm{S}, 34^{\circ} 57^{\prime} \mathrm{W}$ ) the southern one is Pontal do Cupe (Neumann et al. 1998).

\section{Data Sampling and Analysis}

Observations were carried out every month, for two consecutive days, for each of the four selected areas. Time spent on daily observations was of 11 hours, from 6:00 a.m. to 5:00 p.m. from September 2004 to August 2005. It was established that the morning period would go from 6:00 a.m. to 11:30 a.m.; the afternoon period would be between 11:31 a.m. and 5:00 p.m. Sampling was carried out through two seasons, draught (September to February) and rainy (March to August). Pluviometric data (for each month of the year, $\mathrm{N}=12$ ), registered by the weather stations in the municipalities, was acquired on the site of Instituto Tecnológico de Pernambuco (www.itep.br). The Port of Recife tide table (Diretoria de Hidrografia e Navegação da Marinha do Brasil) was used for the observation sites of Olinda, Piedade and Port of Recife; for Port of Suape, its own tide table was used as reference. For tidal analysis two "meteorological tidal" statuses were used: flood and ebb.

Observations were carried out on land, records on behavioral occurrences were noted down at 15-minute intervals. 


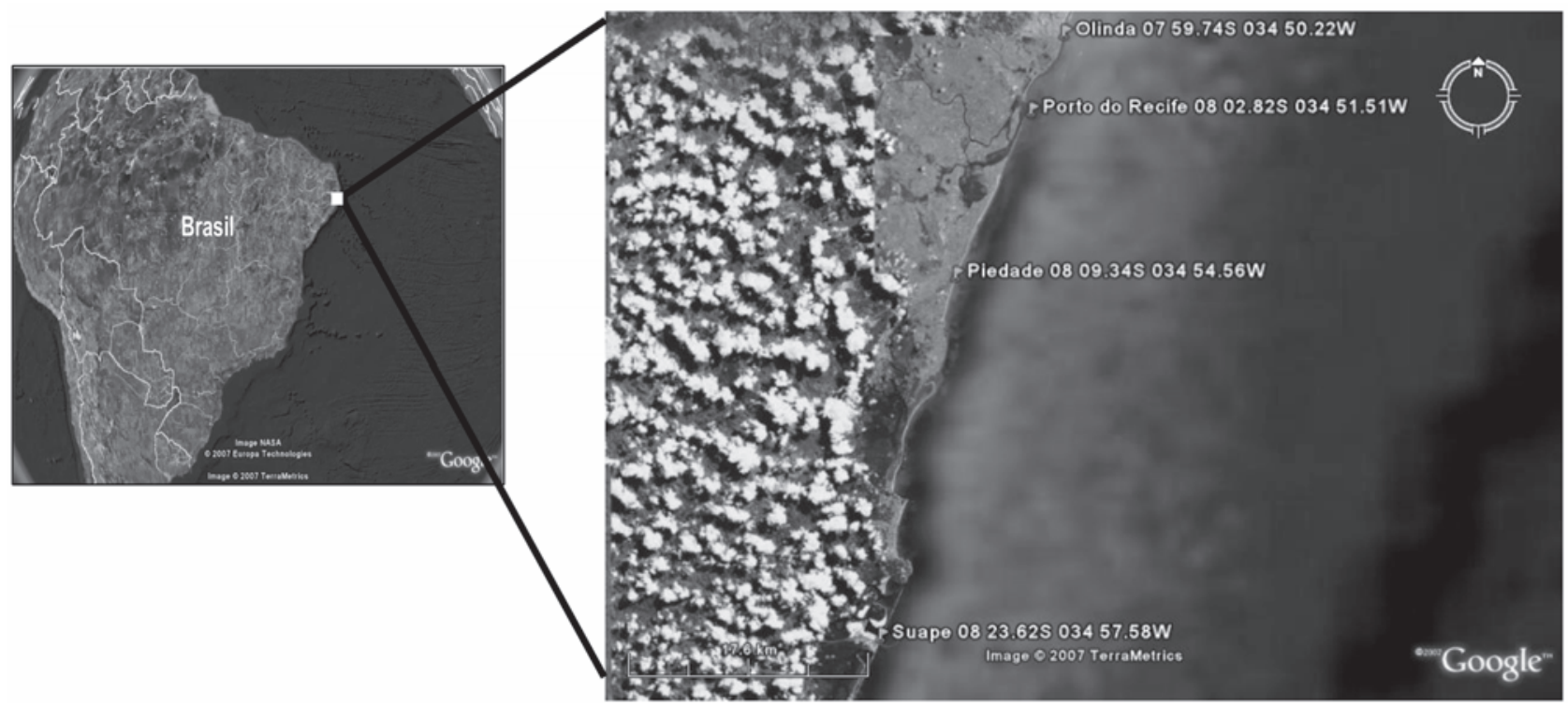

Figure 1. Location of the observation sites for the estuarine dolphin on the coast of Pernambuco.

No individual identifications were carried out; all behaviors were equally recorded, considering their attitudes at the moment they were seen (SLOOTEN 1994).

State and event were considered as different occurrences, where it is assumed that a state involves long-duration behaviors, while an event is an instant occurrence (LEHNER 1996, MARTIN \& BATESON 1998). Definitions of the behavioral events were obtained and adjusted from GeISE (1991), Araújo et al. (2003) and Souto et al. (2006). These are: (1) Swimming ("surfing" and quick diving or "porpoising"); (2) feeding strategies (chase and object controlling); (3) aerial behavior (tailslap, periscope or "spyhopping", pectoral, total leaping, partial leaping, somersault).

It is important to mention that some behaviors are less conspicuous than others. Thus, especially in conditions were a large number of individuals are present and/or the observer is inexperienced, biasing during sampling can occur. However, groups of $S$. guianensis in northeast Brazil usually consist of few individuals (about four animals), a feature that strongly facilitates the precise recording of their behavior. Moreover, the observer (JPA) is well experienced with the behavior of these animals, studying them since 1994. Given these two conditions we consider that biasing during data collection unlikely occurred.

The number of individuals observed (on each 15-minute interval) for each behavioral event was used to calculate frequency behavior. To analyze activity patterns in relation to the variables time, tide and seasonality, as well as to assess time permanence and the mean number of the estuarine dolphins in the studied areas, the Mann-Whitney U Tests was employed. The Spearman correlation test was used to verify relationship between the number of individuals and the pluviometric index. All analyses were carried out by means of the SPSS pro- gram, version 8.0 , the $\mathrm{p} \leqslant 0.05$ (bilateral) level of significance was adopted.

\section{RESULTS}

Ninety-six field outings were performed, which resulted in 1.056 hours of sampling effort (264 hours per site), making a total of 189 hours and 45 minutes of effective behavioral records. Estuarine dolphins were found to be present during longer intervals in the Port of Recife area (100 hours), while in the Port of Suape and on Olinda beach they were seen during 51 and 35 hours, respectively; a significant difference was noticed when relating the Port of Recife with Port of Suape and Olinda beach $\left(\mathrm{n}_{1,2}=11, \mathrm{U}=29.0, \mathrm{U}=19.0, \mathrm{p} \leqslant 0.05\right.$, in both cases). The shortest observation period, regarding estuarine dolphins, occurred at Piedade beach, three hours and 45 minutes; a significant difference was found when relating this beach to the other port areas $\left(\mathrm{n}_{1,2}=11 ; \mathrm{U}=0\right.$, in both cases; $\left.\mathrm{p} \leqslant 0.05\right)$.

Considering the 24 field outings carried out on each site, estuarine dolphins were seen on 22 days in the ports of Recife and Suape, with means of $2.83(\mathrm{SD}=1.24)$ and $2.86(\mathrm{SD}=1.24)$ individuals per area, respectively. They were seen 12 days in Olinda (mean $=1.18, \mathrm{SD}=1.20$ ) and 9 days in Piedade (mean of $1.37, \mathrm{SD}=1.58$ ). The number of days observed in the four areas presented a significant variation when relating the Port of Recife to the beach areas $\left(\mathrm{n}_{1,2}=24, \mathrm{U}=121.5, \mathrm{U}=87.0, \mathrm{p} \leqslant 0.05\right)$. This also was noticed when relating Port of Suape to the other two beaches $\left(n_{1,2}=24, U=148,0, U=80,0, p \leqslant 0,05\right.$, in both cases), where a significant difference was verified.

The number of individuals observed per group, at each 15-minute interval, varied between one and 10 (the maximum number of animals occurred in the Port of Recife). The maxi-

Revista Brasileira de Zoologia 24 (4): 1122-1130, dezembro 2007 
mum number of records in the other sites varied from four to seven estuarine dolphins (Fig. 2).

As to behavioral frequency, tailslap, total leaping, spyhopping, porpoising, partial leaping and chase were mostly recorded in the above order, for the Port of Recife $(96.78 \%)$ and Suape (94.82\%) areas and for Olinda beach (93.24\%). Three other behaviors were recorded in these areas: object controlling, pectoral and somersault, although rare during observations. In Piedade, 100\% of the behavior observed may be understood as a going through activity (total leaping, partial leaping, porpoising and "surfing") (Fig. 3).

Variation on behavioral frequency did not show to be statistically significant (Tab. I), when compared to the morning or afternoon periods, seasonality and tidal levels (Figs 4-6).

Correlation between the mean number of individuals and the pluviometric index was negative for all the studied areas, indicating that when pluviometric indexes are high, a reduction on the number of animals is noted. A significant difference was observed for the Port of Recife area $\left(\mathrm{N}=12, \mathrm{r}_{\mathrm{s}}=-0.64\right.$, $\mathrm{p} \leqslant 0.05)$ and on Olinda beach $\left(\mathrm{N}=12, \mathrm{r}_{\mathrm{s}}=-0.70, \mathrm{p} \leqslant 0.05\right)$.

\section{DISCUSSION}

Estuarine dolphins were seen in a heterogeneous way in the study areas. Among the monitored sites, Piedade beach presented a rare use, being considered as exploratory area according to the definition used by Cremer et al. (2004). Thus, fluctuations on prey availability seem to have a conditioning role both in the frequency parameters, size and group composition, as well as for foraging activities performed by the estuarine dolphins in different study areas (GEISE et al. 1999, ARAújo et al. 2003, Daura-Jorge et al. 2004, Flores \& BAZzalo 2004, DaUraJorge et al. 2005, 2007). Another factor that may influence distribution in relation to the home range limit is predation pressure. This factor limits the use of areas facing the open sea (Cremer et al. 2004). Shark predation on dolphins has been registered in some species (Di Beneditto et al. 1998, Heithaus \& Dill 2001, di BeneditTo 2004). The shark tiger (Galeocerdo cuvier Péron \& LeSueur, 1822) attacks, as well as the bull shark (Carcharhinus leucas Valenciennes, 1839) and backtip shark attacks (C. limbatus Valenciennes, 1839) have been reported for Piedade beach (HAzIN et al. 2000), suggesting that a reduced occurrence of estuarine dolphins in this area could be related to predation risks and/or to prey competition.

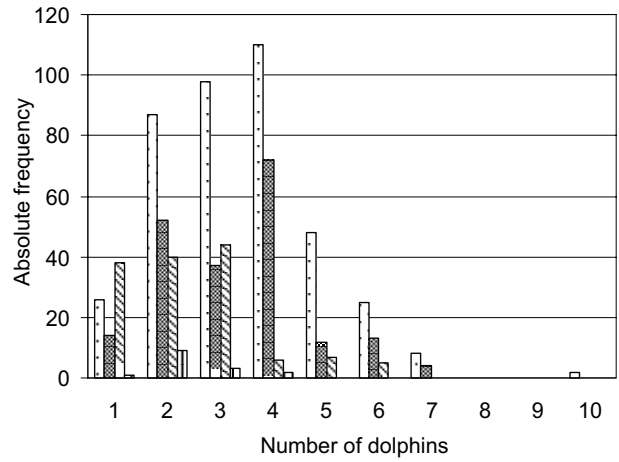

$\square$ Recife $(n=404)$ : Suape $(n=204)$ S Olinda $(n=140)$

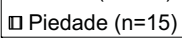

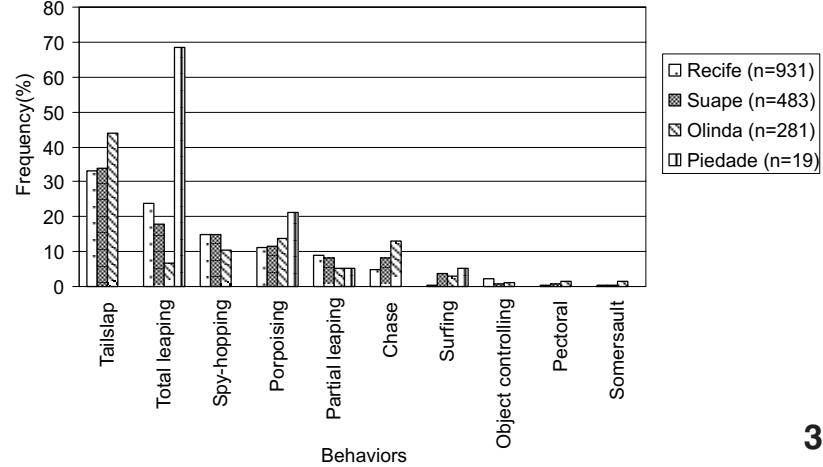

Figures 2-3. (2) Relationship between the number of individuals and absolute frequency of the records in Pernambuco; (3) occurrence frequency of different behaviors shown by Sotalia guianensis in Pernambuco, from September 2004 to August 2005.

Estuarine dolphins were also recorded in another open area, Olinda beach. However, Olinda beach presented use during half of the observational period, being considered occasional area (CREMER et al. 2004).

Among the four studied areas, and according to denominations proposed by CREMER et al. (2004), the ports of Recife and Suape can be considered as concentration areas for such species. These ports have characteristics similar to the inlets reported in other studies. It has been assumed that $S$. guianensis prefer sheltered areas, such as in Enseada de Mucuripe, Ceará (Oliverra et al. 1995), in the Cananéia, São Paulo, estuarine and lagoon system (SANTos et al. 2001), in Baía dos Golfinhos, Rio Grande do Norte (ARAújo et al. 2003), Baía da Guanabara, Rio de Janeiro (Lodi 2003), Baía de Emboraí, Pará (Torres \& BeAsLey

Table I. Significance levels of the Mann-Whitney U Test for relationships between time, seasonality and tides, using the mean number of the observed behaviors for the estuarine dolphin, Pernambuco, from September 2004 to August 2005.

\begin{tabular}{lcccc}
\hline \multicolumn{1}{c}{ Study Areas } & Port of Recife & Port of Suape & Olinda Beach & Piedade Beach \\
\hline Time (morning and afternoon) & 11.5 (n.s.) & 17.0 (n.s.) & 11.5 (n.s.) & 11.5 (n.s.) \\
Seasonality (dry and rainy) & 14.5 (n.s.) & 17.0 (n.s.) & 18.0 (n.s.) & 15.0 (n.s.) \\
Tide (flooding and ebbing) & 16.5 (n.s.) & 18.0 (n.s.) & 11.5 (n.s.) & 11.5 (n.s.) \\
\hline
\end{tabular}

$\mathrm{n}_{1,2}=6 ;$ n. s. $=$ not significant. 

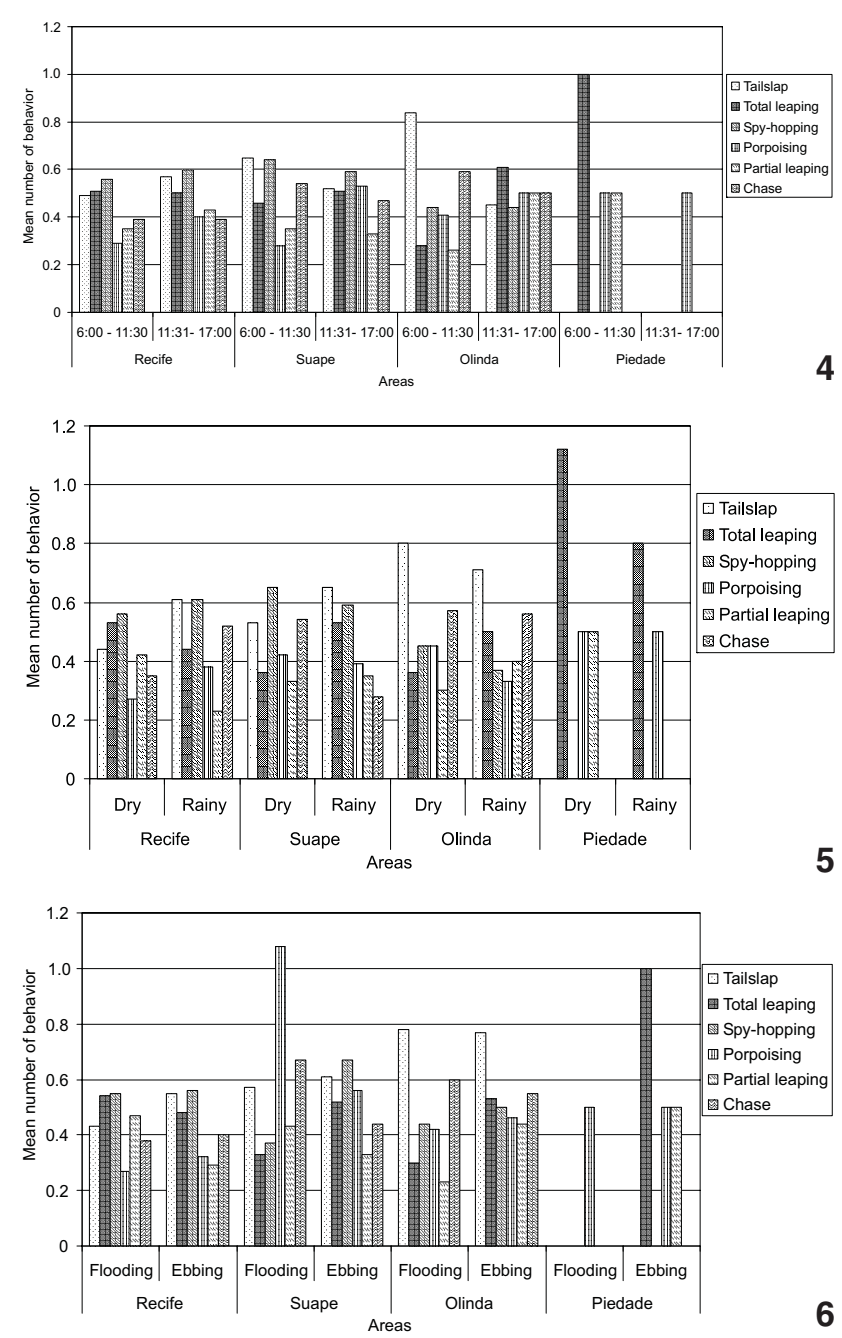

Figures 4-6. Relationships between the mean numbers of the estuarine dolphin behavior and time (4); seasonality (5) and tide (6) per studied areas on the coast of Pernambuco.

2003), and Baía Norte, Santa Catarina (DAURA-Jorge et al. 2005). In none of the previous studies, however, a comparison between open sites and inlets was presented. Our comparative study confirms this preference and also assumes that the inlets provide shelter against predators, as well as feeding abundance (GeISE et al. 1999, SANTOS et al. 2001).

Deep waters (over $10 \mathrm{~m}$ ) are also responsible for a greater occurrence of estuarine dolphins in the ports of Recife and Suape. This preference was also observed in Baía de Sepetiba and Baía da Guanabara, Rio de Janeiro (Simão \& Poletto 2002, Azevedo et al. 2005), showing that estuarine dolphins prefer demersal prey (Simão \& PoletTo 2002). On the other hand, in Cananéia (São Paulo), Baía de Paraty (Rio de Janeiro) and Baía Norte (Santa Catarina), a greater occurrence of estuarine dolphins on shal- low waters was noticed (GeISE et al. 1999, LODI 2003, Flores \& BAZzALO 2004, respectively), which can indicate a possible adaptation flexibility of these animals to each site conditions and characteristics, including the kind of prey to be consumed (MonTEIro et al. 2006). On the coastal region in the South East of Brazil, the $S$. guianensis feeding habit is to capture pelagic and demersal species, showing that such species feed on different depths, both at mud and/or sand substrata, and are typically marine or estuarine dependant (Borobia \& Barros 1989). Some species like Anchoa filifera (Fowler, 1915), Cathrops spixii (Agassiz, 1829), Cynoscion leiarchus (Cuvier, 1830), Diapterus auratus Ranzani, 1842, Harengula clupeola (Cuvier, 1829), Micropogonias furnieri (Desmarest, 1823), Mugil curema Valenciennes, 1836, Pomadasys corvinaeformis (Steindachner, 1868), Pseudupeneus maculates (Bloch, 1793), Trichiurus lepturus Linnaeus, 1758, which are the target species recorded for the S. guianensis (Borobia \& Barros 1989, SANTos et al. 2002, GuRJão et al. 2003, Di BENEDITTO \& Ramos 2004) are found in Pernambuco (Eskinazi 1972, EstatPESCA 2003), being mugilidae one of the selected prey group (Hetzel \& Lodi 1993, Monteiro-Filho 1995, Oliveira et al. 1995, Simão \& Poletto 2002).

Slapping the water surface, as well as total leaping has been associated to fishing activities for the Tursiops truncatus (Würsig \& WÜrsIg 1979). Caudal fin slapping performed by Sotalia guianensis is also used as a foraging strategy (DI BENEDITTO et al. 2001). According to fishing activities recorded in the studied areas it can be said that the main reason for estuarine dolphin permanence is feeding activities.

Estuarine dolphins usually band together in small social groups, in relation to other delphinids (HeTzel \& Lodi 1993). The number of individuals in the four observational sites varied from one to ten and is similar to the ones recorded in Baía dos Golfinhos (Rio Grande do Norte) (Araújo et al. 2003) and Enseada de Mucuripe (Ceará) (Oliveira et al. 1995). However, in Baía de Sepetiba (Rio de Janeiro), groups with up to 88 individuals have been recorded (SIMÃo et al. 2000) and in Baía da Ilha Grande (Rio de Janeiro), groups of at least 450 estuarine dolphins have also been found (Lodi \& HeTzel 1998). Estuarine dolphins gather together forming larger groups in sites where a greater number of prey items are available (AzEvEDo et al. 2005), or for social purposes, including mating and disputes between individuals (NorRis \& DoHL 1980), and/or to reduce the risk of injuries caused by other cetaceans species (WEDEKIN et al. 2004). Results found in this study suggest that the groups of estuarine dolphins in the studied areas show similar gregarious patterns to the ones observed in the North East of Brazil.

The high occurrence of tailslap behavior, seems to be related to the fact that most of the estuarine dolphin prey show demersal habits, thus forcing these animals to use a greater impulse for a long dive, exhibiting the caudal fin above the surface. Seawalls found on the two port areas facilitated prey capturing, as the greatest number of individuals occurred near these obstacles. In such case, the lobtailing behavior can also be used to 
encircle fish shoals against the seawalls. In Cananéia (São Paulo), estuarine dolphins use barriers as a fishing strategy to facilitate prey capturing (MonTeiro-Filho 1995), while in Baía dos Golfinhos (Rio Grande do Norte), these animals were observed herding the fish shoal to an enclosed area and taking positions to trap prey (ARAÚjo et al. 2003). It is believed that the tailslap behavior, as well as leaps may be used to force fish school displacement to a specific direction, thus facilitating prey capturing.

The chase behavior was found to be more frequent in Olinda and can be related to a smaller number of individuals in this area; thus, a greater number of this behavior is needed, as cooperation between individuals facilitates the hunting (Souto et al. 2006). A greater number of individuals observed in the port areas may justify dolphins ability to encircle the fish shoal to control prey evasion. This fact indicates an inverse correlation between the number of individuals and the fishing effort, regarding energy expenditure (Souto et al. 2006). Chase behavior in Baía dos Golfinhos (Rio Grande do Norte) was also selected when few individuals were present in that area, as this would be the most efficient way to capture prey at random, without forming strategic groups (ARAújo et al. 2003). Porpoising behavior can also be associated to swimming, helping animals to move at a greater speed without greater metabolic expenditure (GeIse 1991).

The most frequent behaviors (total leaping, porpoising and surfing) at Piedade beach seem to help the estuarine dolphins to move to other areas. Their quick passage by Piedade may also be related to shark presence in that site.

The spy-hopping behavior was related to fishing by CONNOR \& SMOLKer (1985) to play by Geise (1991), to the waking up activity by NorRIs \& DOHL (1980), and just as an observation behavior by ARAújo et al. (2003). That behavioral event was one of the most verified ones in this study. Probably, the use of such behavior enabled dolphins to locate fish shoals, as it had only been recorded in areas where fishing activities were evident.

In the four studied areas, no relationship between behavior and time was noted. Some studies (Oliveira et al. 1995, Geise et al. 1999, Araújo et al. 2003), however, correlate different times with a greater frequency among the different kinds of animal immigration and emigration swimming (LoDI 2003). Estuarine dolphins did not show a definite time pattern for entering and leaving the areas concerning this study; a constant movement during the whole day round took place in the study sites.

Regarding the relationship between behavior and seasonality, no significant difference was found. Similar results were verified for other areas in the country, where estuarine dolphins are present during the whole year round (GeIse et al. 1999, Araújo et al. 2003, Azevedo et al. 2005). This fact could be related to the weather characteristics of the tropical region, where a clear seasonality is not present (ANDRADE \& Lins 2005). In Baía Norte (Santa Catarina), during winter and autumn months, a possible increase on these animals movement can be noticed, influenced by prey availability and due to a greater demand of energy expended by the estuarine dolphins to maintain body temperature (Daura-Jorge et al. 2004, Flores \& Bazzalo 2004).

The negative correlation between the average number of estuarine dolphins and the pluviometric index may indicate that the sound of rain hitting the water could mask their whistles, making communication between these animals difficult, by comprising a similar sound frequency (GERSTEIN 2002, PIVAri \& Rosso 2005). When this takes place during foraging, estuarine dolphins move to deeper waters, where the sound of rain is not so strong. This hypothesis can be corroborated by a study carried out with the manatee, Trichechus manatus (Linnaeus, 1758), in Florida, where the average sound in the environment is generally of 70 decibels, but can reach 90 decibels when a light rain is falling (GERSTeIN 2002).

In the present study, no significant difference between behavior and tide level was found. However, some studies associate different tides to the frequency of individuals (Oliverra et al. 1995, Araújo et al. 2003, LODI 2003). Fishes entering the area is probably related to flood tide (WÜrSIG \& WÜrSIG 1979). On the other hand less water in the environment during reflux of tide facilitates the search for food (Oliveira et al. 1995). It is believed that estuarine dolphins can take advantage of these two peculiar tidal levels in the feeding areas.

The residence pattern observed in this study may be due to food availability in a determined site. It is known, for instance, that prey abundance favors a great fidelity to the use of a certain area in Sousa chinensis (Osbeck, 1765) (KARCZMARSKI 1999). A greater quantity of domestic effluents in Port of Recife will probably result in an increase of opportunistic fish; dredging carried out in the areas within the ports may also contribute to this fact. Moreover, the preference for calm waters (Lodi \& HeTzeL 1998, GeIsE et al. 1999), as in the ports, possibly contributed to the greater presence of the estuarine dolphins in those locations.

\section{ACKNOWLEDGEMENTS}

We are grateful to the two anonymous referees for valuable suggestions that improved the manuscript. To Walter Blossey and to Luiz G. Mascarenhas for authorizing observations in Complexo Industrial and Portuário de Suape, making this study possible. To Valdir Manso from Laboratório de Geologia and Geofísica Marinha UFPE, for the depth data of the studied areas. To the university staff; Ana Maria Alves, Bárbara Neves, Bruno Paes, Carolinne Ramos, Clayton Fernandes, Cristiane Figueiredo, Dayana Freitas, Eric Nascimento, Milena Monteiro and Raphael Neves, for their help in the field work. To CAPES/UFPE Doctorate grant (JPA).

\section{REFERENCES}

Andrade, G.O. \& R.C. Lins. 2005. Os climas do nordeste, p. 95138. In: J. VASCONCELOS Sobrinho (Ed.). As regiões naturais do Nordeste, o meio e a civilização. Recife, CONDEPE, 273p.

Revista Brasileira de Zoologia 24 (4): 1122-1130, dezembro 2007 
Araúuo, J.P.; J.Z.O. Passavante \& A.S. Souto. 2003. Behavior of the estuarine dolphin, Sotalia guianensis, at Dolphin Bay Pipa - Rio Grande do Norte - Brazil. Tropical Oceanography 31 (2): 101-112.

Azevedo, A.F.; S.C. Viana; A.M. Oliveira \& M. van Sluys. 2005. Group characteristics of marine tucuxi (Sotalia fluviatilis) in Guanabara Bay, south-eastern Brazil. Journal of the Marine Biological Association of the United Kingdom 85: 209-212.

Azevedo, A.F.; A.M. Oliveira; S.C. Viana \& M. van Sluys. 2007. Habitat use by marine tucuxis (Sotalia guianensis) (Cetacea: Delphinidae) in Guanabara Bay, south-eastern Brazil. Journal of the Marine Biological Association of the United Kingdom 87: 201-205.

Barros, N.B. \& R.L. Teixeira. 1994. Incidental catch of marine tucuxi, Sotalia fluviatilis, in Alagoas, Northeastern Brazil. Report International Whaling Commission. Special Issue 15: 265-268.

BEISSINGER, S.R. 1997. Integrating behavior into conservation biology: potentials and limitations, p. 23-47. In: J. R. CLEMMONS $\&$ R. BuchHolz (Eds). Behavioral approaches to conservation in the wild. Cambridge, University Press, 376p.

Bittencourt, M.L. 1984. Primeira ocorrência de Sotalia brasiliensis (boto), Cetacea Delphinidae, para a Baía de Paranaguá, Litoral Paranaense, Brasil. Arquivo de Biologia e Tecnologia do Paraná 27 (1): 95-98.

Borobia, M. \& N.B. Barros. 1989. Notes on the diet of marine Sotalia fluviatilis. Marine Mammal Science 5 (4): 395-399.

Borobia, M.; S. Siciliano; L. Lodi \& W. Hoek. 1991. Distribution of the South American dolphin Sotalia fluviatilis. Canadian Journal of Zoology 69: 1025-1039.

ConNor, R.C. \& R.S. SMOLKER. 1985. Habituated dolphins (Tursiops sp.) in Western Australia. Journal of Mammalogy 66 (2): 398-400.

Cremer, M.J.; F.A.S. Hardt; A.J. Tonello Júnior; P.C.A. Simões-Lopes $\&$ J.S. PIres. 2004. Core areas changes in Sotalia guianensis (Cetacea, Delphinidae) population in Babitonga Bay, Santa Catarina. Revista Univille 9: 12-16.

Cunha, H.A.; V.M.F. Silva; J. Lailson-Brito Júnior; M.C.O. Santos; P. A.C. Flores; A.R. Martin; A.F. Azevedo; A.B.L. Fragoso; R.C. Zanelatto \& A.M. Solé-Cava. 2005. Riverine and marine ecotypes of Sotalia dolphins are different species. Marine Biology 148: 449-457.

DA SiLva, V.M.F. \& R.C. BeST. 1996. Sotalia fluviatilis. Mammalian Species 527: 1-7.

Daura-Jorge, F.G.; L.L. Wedekin \& P.C. Simões-Lopes. 2004. Variação sazonal na intensidade dos deslocamentos do boto-cinza, Sotalia guianensis (Cetacea: Delphinidae), na Baía Norte da Ilha de Santa Catarina. Biotemas 17: 203-216.

Daura-Jorge, F.G.; L. Wedekin; V.Q. Piacentini \& P.C. Simões-Lopes. 2005. Seasonal and daily patterns of group size, cohesion and activity of the estuarine dolphin, Sotalia guianensis (P.J. Van Bénéden) (Cetacea, Delphinidae), in southern Brazil. Revista Brasileira de Zoologia 22 (4): 1014-1021.
Daura-Jorge, F.G.; M.R. Rossi-Santos; L.L. Wedekin \& P.C. SimõesLOPES. 2007. Behavioral patterns and movement intensity of Sotalia guianensis (P.J. van Bénéden) (Cetacea, Delphinidae) in two different areas on the Brazilian coast. Revista Brasileira de Zoologia 24 (2): 265-270.

Di BeneditTo, A.P.M. 2004. Presence of franciscana dolphin (Pontoporia blainvillei) remains in the stomach of a tiger shark (Galeocerdo cuvieri) captured in Southeastern Brazil. Aquatic Mammals 30 (2): 311-314.

Di Beneditto, A.P.M. \& R.M.A. Ramos. 2004. Biology of the marine tucuxi dolphin (Sotalia fluviatilis) in south-eastern Brazil. Journal of the Marine Biological Association of the United Kingdom 84: 1245-1250.

Di Beneditto, A.P.M.; R.M.A. Ramos \& N.R.W. Lima. 1998. Fishing activity in Northern Rio de Janeiro State, BR and its relationship with the small cetaceans. Brazilian Archives of Biology and Technology 41 (3): 296-302.

Di Beneditto, A.P.M.; R.M.A. Ramos \& N.R.W. Lima. 2001. Os golfinhos: origem, classificação, captura acidental, hábito alimentar. Porto Alegre, Cinco Continentes, 147p.

Eskinazi, A.M. 1972. Peixes do Canal de Santa Cruz - Pernambuco - Brasil. Trabalhos Oceanográficos 13: 283-302.

Estatpesca. 2003. Boletim Estatístico da Pesca Marítima e Estuarina do Nordeste do Brasil. Tamandaré, Centro de Pesquisa e Gestão de Recursos Pesqueiros do Litoral Nordeste. CEPENE, 197p.

Flores, P.A.C. 1999. Preliminary results of a photoidentification study of the marine tucuxi Sotalia fluviatilis in southern Brazil. Marine Mammal Science 15 (3): 840-847.

Flores, P.A.C. \& M. BAzzAlo. 2004. Home ranges and movement patterns of the marine tucuxi dolphin, Sotalia fluviatilis, in Baía Norte, southern Brazil. Latin American Journal of Aquatic Mammals 3 (1): 37-52.

Garcia, C. \& F. Trujillo. 2004. Preliminary observations on habitat use patterns of the marine tucuxi, Sotalia fluviatilis, in Cispatá Bay, Colombian Caribbean coast. Latin American Journal of Aquatic Mammals 3 (1): 53-59.

GeISE, L. 1991. Sotalia guianensis (Cetacea, Delphinidae) population in the Guanabara Bay, Rio de Janeiro, Brazil. Mammalia 55 (3): 371-379.

Geise, L.; N. Gomes \& R. Cerqueira. 1999. Behaviour, habitat use and population size of Sotalia fluviatilis (Gervais, 1853) (Cetacea, Delphinidae) in the Cananéia estuary region, São Paulo, Brazil. Revista Brasileira de Biologia 59 (2): 183-194.

Gerstein, E.R. 2002. Manatees, bioacoustics and boats. American Science Online 90 (2): 154.

Gurjão, L.M.; M.A.A. Furtado Neto; R.A. Santos \& P. Cascon. 2003. Feeding habits of marine tucuxi, Sotalia fluviatilis, at Ceará State, Northeastern Brazil. Latin American Journal of Aquatic Mammals 2 (2): 117-122.

Hazin, F.H.V.; J.A.M. Wanderley Júnior \& S.M.G. Mattos. 2000. Distribuição e abundância relativa de tubarões no litoral de Pernambuco, Brasil. Arquivo de Ciências do Mar 33: 33-42. 
Heithaus, M.R. \& L.M. Dill. 2001. Food availability and tiger shark predation risk influence bottlenose dolphin habitat use. Ecology 83 (2): 480-491.

Hetzel, B. \& L. Lodi. 1993. Baleias, botos e golfinhos: guia de identificação para o Brasil. Rio de Janeiro, Nova Fronteira, 279p.

KarCZMARSKI, L. 1999. Group dynamics of humpback dolphins Sousa chinensis in the Algoa Bay region, South Africa. Journal of Zoology 249: 283-293.

Lehner, P.N. 1996. Handbook of ethological methods. Cambridge, University Press, 672p.

LoDI, L.F. 2003. Seleção e uso do habitat pelo boto-cinza, Sotalia guianensis (van Bénéden, 1864) (Cetacea, Delphinidae), na Baía de Paraty, Estado do Rio de Janeiro. Bioikos 17 (1/2): $5-20$.

Lodi, L. \& B. Hetzel. 1998. Grandes agregações do boto-cinza (Sotalia fluviatilis) na Baía da Ilha Grande, Rio de Janeiro. Bioikos 12 (2): 26-30.

Martin, P. \& P. BAteson. 1998. Measuring behaviour: an introductory guide. Cambridge, University Press, 222p.

Monteiro-Filho, E.L.A. 1995. Pesca interativa entre o golfinho Sotalia fluviatilis guianensis e a comunidade pesqueira da Região de Cananéia. Boletim do Instituto de Pesca 22 (2): 15-23.

Monteiro-Filho, E.L.A.; L.R. Monteiro \& S.F. Reis. 2002. Skull shape and size divergence in dolphins of the Genus Sotalia: A tridimensional morphometric analysis. Journal of Mammalogy 83 (1): 125-143.

Monteiro, M.S.; A. Souto \& L.F. Nascimento. 2006. Comparações entre os comportamentos de forrageio nas diferentes faixas etárias do boto-cinza (Sotalia guianensis) (Cetacea; Delphinidae) na Baía dos Golfinhos, Praia de Pipa, RN, Brasil. Revista de Etologia 8 (1): 13-25.

Neumann, V.H.; C. Medeiros; L. Parente; S. Neumann-Leitão \& M.L. Koening. 1998. Hydrodynamism, sedimentology, geomorphology and plankton changes at Suape area (Pernambuco-Brazil) after a Port Complex Implantation. Anais Academia Brasileira de Ciências 70 (2): 313-323.

NorRIS, K.S. \& T.P. DoHL. 1980. The behavior of the hawaiian spinner porpoise, Stenella longirostris. Fishery Bulletin 77: 821-849.

Nunes, J.L.S. \& M.R.B. Machado. 2001. Encalhe de um exemplar de boto-cinza, Sotalia fluviatilis (Gervais, 1853) (Mammalia:Cetacea:Delphinidae) na Praia do Araçagy, São Luis, Estado do Maranhão, Brasil. Boletim do Laboratório de Hidrobiologia 13: 109-112.

Oliveira, J.A. De; F.J.C. Ávila; T.T. Alves Júnior; M.A.A. FurtadoNeto \& C. Monteiro-Neto. 1995. Monitoramento do boto cinza, Sotalia fluviatilis (Cetacea: Delphinidae) em Fortaleza, Estado do Ceará, Brasil. Arquivo de Ciências do Mar 29 (1-2): 28-35.

Parente, C.L.; R.P. Lima \& J.E. Vergara-Parente. 2006. Ocorrência e comportamento de um Sotalia fluviatilis solitário no Nor- deste do Brasil: quando considerar um encalhe? Arquivo de Ciências do Mar 39: 74-80.

Pereira, L.C.C.; P.N. Coutinho; S.J. Macedo \& R.A.A.M. Costa. 1996. Efeitos de estruturas de proteção costeira nas praias de Casa Caiada e Rio Doce - PE, Brasil. Trabalhos Oceanográficos 24: 19-37.

Pivari, D. \& S. Rosso. 2005. Whistles of small groups of Sotalia fluviatilis during foraging behavior in southeastern Brazil. Journal of Acoustic Society of America 118 (4): 2725-2731.

Resurreição, M.G.; J.Z.O. Passavante \& S.J. Macedo. 1996. Estudo da plataforma continental na área do Recife (Brasil): variação sazonal da biomassa fitoplanctônica (08 $03^{\prime}$ 38" Lat. S; 34 $42^{\prime} 28^{\prime \prime}$

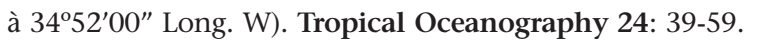

Rosas, F.C.W.; A.S. Barreto \& E.L.A. Monteiro-Filho. 2003. Age and growth of the estuarine dolphin (Sotalia guianensis) (Cetacea, Delphinidae) on the Paraná coast, southern. Fishery Bulletin 101: 377-383.

Rosas, F.C.W. \& E.L.A. Monteiro-Filho. 2002. Reproduction of the estuarine dolphin (Sotalia guianensis) on the coast of Paraná, southern Brazil. Journal of Mammalogy 83 (2): 507-515.

Rossi-Santos, M.R.; L.L. Wedekin \& E.L.A. Monteiro-Filho. 2007. Residence and site fidelity of Sotalia guianensis in the Caravelas River Estuary, eastern Brazil. Journal of the Marine Biological Association of the United Kingdom 87: 207-212.

SAnTos, M.C. DE O.; L.B. Acuña \& S. Rosso. 2001. Insights on site fidelity and calving intervals of the marine tucuxi dolphin (Sotalia fluviatilis) in south-eastern Brazil. Journal of the Marine Biological Association of the United Kingdom 81: 1049-1052.

Santos, M.C. De O.; S. Rosso; R.A. Santos; S.H.B. Lucato \& M. BASSOI. 2002. Insights on small cetacean feeding habits in southeastern Brazil. Aquatic Mammals 28 (1): 38-45.

SimÃo, S.M. \& F.R. Poletto. 2002. Áreas preferenciais de pesca e dieta do ecótipo marinho do boto-cinza (Sotalia fluviatilis) na Baía de Sepetiba, RJ. Floresta e Ambiente 9 (1): 18-25.

SimÃo, S.M.; J.L.A. Pizzorno; V.N. Perry \& S. Siciliano. 2000. Aplicação da técnica de fotoidentificação do boto-cinza, Sotalia fluviatilis (Cetacea, Delphinidae) da Baía de Sepetiba. Floresta e Ambiente 7 (1): 31-39.

SIMÕES-LoPES, P.C. 1988. Ocorrência de uma população de Sotalia fluviatilis, Gervais, 1853 (Cetacea, Delphinidae) no limite sul de sua distribuição, Santa Catarina, Brasil. Biotemas 1 (1): 57-62.

SLooten, E. 1994. Behavior of Hektor's dolphin: classifying behavior by sequence analysis. Journal of Mammalogy 75 (4): 956-964.

Souto, A.; J.P. Araújo; L. Geise \& M.E. Araújo. 2006. The surface behaviour of the estuarine dolphin in Baía dos Golfinhos, RN, Brazil: a field and comparative study. Revista Brasileira de Zoociências 8 (2): 183-192.

Sousa, G.S. \& A.L.M. Cocentino. 2004. Macroalgas como indicadoras da qualidade ambiental da Praia de Piedade - 
PE. Tropical Oceanography 32 (1): 1-22.

Torres, D. \& C.R. Beasley. 2003. Pattern of use a small bay in northern Brazil by Sotalia guianensis (Cetacea: Delphinidae). Amazoniana 17 (3/4): 586-597.

Wedekin, L.L.; F.G. Daura-Jorge \& P.C. Simões-Lopes. 2004. An aggressive interaction between bottlenose dolphins (Tursiops truncatus) and estuarine dolphins (Sotalia guianensis) in Southern Brazil. Aquatic Mammals 30 (3): 391-397.
Wedekin, L.L.; F.G. Daura-Jorge; V.Q. Piacentini \& P.C. SimõesLopes. 2007. Seasonal variation on the spatial use of the estuarine dolphin, Sotalia guianensis (Cetacea, Delphinidae) in its southern limit of distribution. Brazilian Journal of Biology 67 (1): 1-8.

Würsig, B. \& M. Würsig. 1979. Behavior and ecology of the bottlenose dolphin, Tursiops truncatus, in the South Atlantic. Fishery Bulletin 77 (2): 399-412.

Received in 23.VII.2007; accepted in 26.XI.2007. 